\title{
Kebijakan Pemerintah Daerah Dalam Melindungi Identitas Budaya Dan Hak Tradisional Masyarakat Hukum Adat Kabupaten Batang Hari
}

\section{Policy Of Local Government In Protecting Cultural Legal Community Traditional Identities And Rights Batang Hari District}

\author{
Firmansyah Putra ${ }^{1}$, Citra Darminto ${ }^{2}$ \\ Universitas Jambi, Indonesia \\ firmansyahputra@unja.ac.id, darmintocitra2014@gmail.com
}

\begin{abstract}
Abstrak. Dalam penelitian ini, penulis menggunakan pendekatan kualitatif adalah suatu metode penelitian yang berlandaskan pada filsafat postpositivisme, digunakan untuk meneliti pada kondisi objek yang alamiah dimana peneliti adalah sebagai instrumen kunci untuk mencari masalah terkait kebijakan pemerintah daerah batang hari kemudian menganalisis penyebab masalah tersebut kemudian mencari solusi dan mengantisipasi masalah tersebut muncul kembali. Perbedaan suku, budaya dan adat istiadat suatu bangsa merupakan suatu Realitas sosial budaya bangsa Indonesia, dan hal ini menunjukan betapa eksisnya kesadaran primordial dalam kehidupan bangsa Indonesia, disamping merupakan kondisi alamiah disyukuri dan dikagumi, tetapi juga harus diwaspadai karena memiliki intensitas konflik yang cukup tinggi. Kebudayaan memberi bentuk kepada sikap hidup, sikap mental warga, dan pola hidup masyarakat sehari-hari. Sebaliknya, sikap dan pola hidup itu juga Memberi bentuk kepada kebudayaan. Kebudayaan itu dipelajari dan kebudayaan itu beradaptasi serta berkembang. Budaya daerah memiliki sejarah panjang dan memiliki kearifan dan keunggulannya masing-masing. Pada dirinya masing-masing, budaya itu mengandung unsur-unsur yang oleh para founding fathers kita disarikan dalam pancasila. Adat istiadat dan nilai sosial budaya masyarakat merupakan salah satu modal sosial yang dapat dimanaatkan dalam rangka pelaksanaan pembangunan. Pelestarian dan pengembangan adat istiadat dan nilai sosial budaya masyarakat dibangun dengan mengkedepankan tiga pilar utama yaitu pilar pengembangan ekonomi masyarakat, pilar pelestarian dan pilar kemandrian masyarakat. Pada akhirnya diperlukan suatu kebijakan pemerintah daerah untuk melindungi Identitas Budaya Dan Hak Tradisional Masyarakat adalah suatu keharusan.
\end{abstract}

Kata Kunci : Pemerintah Daerah, Budaya, Hak, Masyarakat Hukum Adat.

Abstract. In this study, the author uses a qualitative approach is a research method based on the philosophy of postpositivism, used to examine the natural conditions of objects where researchers are as a key instrument to look for problems related to local government policies and then analyze the causes of these problems then find solutions and anticipate the problem reappeared. The differences in ethnicity, culture and customs of a nation is a social cultural reality of Indonesia, and this shows how the existence of primordial awareness in the life of the Indonesian nation, besides being a natural condition to be grateful and admired, must also be wary because it has a high enough conflict intensity. Culture gives shape to people's attitudes, people's mental attitudes, and people's daily life patterns. Instead, attitudes and patterns of life also give shape to culture. Culture is learned and the culture adapts and develops. Regional culture has a long history and has its own wisdom and superiority. In each of them, the culture contains elements that our founding fathers extract in the Pancasila. Customs and sociocultural values of society are one of the social capital that can be utilized in the context of implementing development. Preservation and development of customs and socio-cultural values of the community was built by prioritizing three main pillars, namely the pillar of community economic development, the preservation pillar and the pillar of the independence of the community. In the end, a local government policy is needed to protect Cultural Identities and Traditional Rights of the Community is a must.

Keywords : Local Government, Cultural, Rights, Customary Law Communities. 
Terakreditasi Peringkat 5 (No. SK: 85/M/KPT/2020)

\section{PENDAHULUAN}

Istilah Masyarakat Hukum Adat merupakan terjemahan dari istilah rechtsgemeenchappen. Istilah ini pertama kali ditemukan dalam buku Mr. B. Ter Haar Bzn. yang berjudul "Beginselen en Stelsel van Hat Adat Recht". Pada amandemen kedua Undang-Undang Dasar Negara R.I Tahun 1945, secara khusus pada ketentuan Pasal 18 B Ayat 2. Pengaturan mengenai Masyarakat Hukum Adat ditempatkan sebagai bagian dari pengaturan tentang Pemerintah Daerah. Istilah yang digunakan di dalam Pasal tersebut adalah kesatuan-kesatuan Masyarakat Hukum Adat. Dalam Undang-Undang Nomor 5 Tahun 1960 tentang Peraturan Dasar PokokPokok Agraria, secara khusus pada Pasal 2 Ayat (4) yang mengatur bahwa "Hak menguasai dari Negara tersebut diatas pelaksanaannya dapat dikuasakan kepada daerah-daerah Swatantra dan masyarakatmasyarakat hukum adat, sekedar diperlukan dan tidak bertentangan dengan kepentingan nasional, menurut ketentuan-ketentuan Peraturan Pemerintah".

Secara gramatikal, kata "masyarakat" di dalam kamus besar bahasa Indonesia mengartikan sebagai sejumlah manusia dalam arti seluas-luasnya dan terikat oleh suatu kebudayaan yang mereka anggap sama. "Adah" atau "adat" artinya kebiasaan yaitu perilaku masyarakat yang selalu senantiasa terjadi di dalam kehidupan masyarakat seharihari. Dengan begitu yang dimaksud hukum adat adalah hukum kebiasaan. Menurut Maria SW Sumardjono, beberapa ciri pokok masyarakat hukum adat adalah mereka merupakan suatu kelompok manusia, mempunyai kekayaan tersendiri terlepas dari kekayaan perorangan, mempunyai batas wilayah tertentu dan mempunyai kewenangan tertentu.

Potensi multi tafsir misalnya dapat dilihat dari aspek siapa yang termasuk dalam Masyarakat Hukum Adat tersebut. Hal tersebut menimbulkan perdebatan tentang identitas personal individu yang berada dalam kelompok Masyarakat Hukum Adat, berkaitan dengan pengakuan menyangkut hubungan kelompok (Masyarakat Hukum Adat) dengan perorangan sebagai anggota dalam satu kesatuan Masyarakat Hukum Adat.

$$
\text { Undang-Undang Dasar Republik }
$$

Indonesia 1945 menempatkan posisi negara untuk mengakui dan menghormati setiap hakhak tradisional dari masyarakat hukum adat yang masih hidup dan terpelihara hingga saat ini. Dengan dicantumkannya pengakuan dan penghormatan terhadap suatu hak tradisional maka adat yang merupakan bagian dari hak tradisional merupakan sebuah hak konstitusi yang juga merupakan hak asasi manusia. Dalam konstitusi hak tradisional masyarakat hukum adat diatur dalam Pasal 18 B ayat (2) UUD NRI Tahun 1945 yang menyatakan bahwa, "Negara mengakui dan menghormati kesatuan-kesatuan masyarakat hukum adat beserta hak-hak tradisionalnya sepanjang masih hidup dan sesuai dengan perkembangan masyarakat dan prinsip Negara Kesatuan Republik Indonesia, yang diatur dalam undangundang”. Berdasarkan rumusan Pasal tersebut maka dapat diuraikan bahwa:

a. bahwa negara mengakui keberadaan kesatuan masyarakat hukum adat memang sudah ada sebelum Negara Kesatuan Republik Indonesia didirikan dan UUD 1945 disahkan;

b. kesatuan masyarakat hukum adat yang diakui itu haruslah terbukti masih hidup;

c. pengakuan itu dapat berubah dinamis mengikuti perkembangan masyarakat dalam arti perkembangan zaman di mana perasaan kemanusiaan dan tingkat peradaban tumbuh dan berkembang sedemikian rupa sehingga pengakuan atas keberadaan kesatuan masyarakat hukum adat beserta hak-hak tradisionalnya itu juga harus disesuaikan dengan kebutuhan menurut ruang dan waktunya yang dinamis itu;

d. pengakuan itu juga tidak boleh bertentangan dengan prinsip dan kepentingan Negara Kesatuan Republik Indonesia, misalnya, di daerah perbatasan jangan sampai pengakuan ini dapat berdampak negatif kepada semangat persatuan bangsa dan integritas wilayah NKRI karena wilayah hukum adat yang 
Terakreditasi Peringkat 5 (No. SK: 85/M/KPT/2020)

bersangkutan melampuai batas wilayah hukum teritorial NKRI; dan

e. bahwa syarat dan prosedur pengakuan terhadap kesatuan masyarakat hukum adat beserta hak-hak tradisionalnya itu harus diatur dengan undang-undang ataupun dalam pelbagai undang-undang lain yang terkait.

Pengaturan mengenai hak tradisional juga terdapat dalam Pasal 28 I Ayat (2) UUD NRI Tahun 1945 yang menyatakan bahwa, "Identitas budaya dan hak masyarakat tradisional dihormati selaras dengan perkembangan zaman dan peradaban". Jika dicermati maka terdapat perbedaan istilah yang digunakan dalam Pasal 18 B Ayat (2) dan Pasal 28 I Ayat (2) UUD NRI Tahun 1945. Dalam Pasal 18 B ayat (2) UUD NRI Tahun 1945 menggunakan istilah "masyarakat hukum adat" dan "hak tradisional" sedangkan Pasal 28 I Ayat (3) UUD NRI Tahun 1945 menggunakan istilah "hak masyarakat tradisional". Dalam terjemahan Konvensi Masyarakat Hukum Adat Tahun 1989 disebutkan bahwa, "Indigenous and tribal peoples" diterjemahkan menjadi Masyarakat Hukum Adat sesuai dengan istilah yang dipergunakan Komnas HAM dan Mahkamah Konstitusi. Terjemahan lain yang umum digunakan adalah masyarakat adat dan masyarakat tradisional". Dengan demikian baik istilah "masyarakat hukum adat" dan "masyarakat tradisional" dalam Pasal 18 B Ayat (2) dan Pasal 28 I Ayat (2) UUD NRI Tahun 1945 dapat dianggap mempunyai kesamaan maksud/arti. Terlebih kedua pasal tersebut sama-sama hasil dari amandemen kedua UUD 1945 pada tahun 2000.

Berdasarkan penjelasan Pasal 6 Ayat (1) Undang-Undang Nomor 39 Tahun 1999 menyatakan bahwa:

Hak adat yang secara nyata masih berlaku dan dijunjung tinggi di dalam lingkungan masyarakat hukum adat harus dihormati dan dilindungi dalam rangka perlindungan dan penegakan hak asasi manusia dalam masyarakat yang bersangkutan dengan memperhatikan hukum dan peraturan perundang-undangan.
Selanjutnya penjelasan Pasal 6 Ayat (2) menyatakan bahwa:

Dalam rangka penegakan hak asasi manusia, identitas budaya nasional masyarakat hukum adat, hak-hak adat yang masih secara nyata dipegang teguh oleh masyarakat hukum adat setempat, tetap dihormati dan dilindungi sepanjang tidak bertentangan dengan asas-asas negara hukum yang berintikan keadilan dan kesejahteraan rakyat.

Perlakuan diskriminasi dapat dilihat dari berbagai kebijakan yang hadir masih belum menjunjung tinggi perlindungan dan penghormatan hak masyarakat hukum adat. Persoalan yang terjadi seringkali karena adanya upaya pembangunan yang dilaksanakan oleh pemerintah hanya didasarkan pada kebijakan sepihak semata dan tidak pernah mengikutsertakan masyarakat hukum adat dalam tiap tahapan pembuatan kebijakan tersebut. Akibatnya, masyarakat hukum adat hanya dianggap sebagai obyek dalam tiap kebijakan sehingga terjadinya penindasan, kekerasan, kriminalisasi dan bahkan perampasan hak-hak masyarakat hukum adat.

Seiring dengan pelaksanaan kebijakan otonomi daerah, maka peran aktif daerah menjadi strategis untuk melaksanakan upayaupaya pemajuan kesejahteraan masyarakat yang pada hakekatnya merupakan tujuan negara yang telah diamanatkan oleh konstitusi. Salah satunya dengan melakukan upaya perlindungan, penghormatan dan pemberdayaan terhadap masyarakat hukum adat dan kelembagaan adat yang ada di daerah. Penyelenggaraan pemerintah daerah menurut asas otonomi maksudnya ialah pemerintah daerah memiliki hak, wewenang, dan kewajiban daerah otonom untuk mengatur dan mengurus sendiri Urusan Pemerintahan dan kepentingan masyarakat setempat dalam sistem Negara Kesatuan Republik Indonesia. Sedangkan yang dimaksud dengan penyelenggaraan urusan pemerintah daerah menurut tugas pembantuan ialah penugasan dari Pemerintah Pusat kepada daerah otonom untuk melaksanakan sebagian Urusan Pemerintahan yang menjadi kewenangan 
Pemerintah Pusat atau dari Pemerintah Daerah provinsi kepada Daerah kabupaten/kota untuk melaksanakan sebagian Urusan Pemerintahan yang menjadi kewenangan Daerah provinsi.

Perlindungan dan penghormatan terhadap identitas budaya dan hak tradisional masyarakat hukum adat hanya akan dapat dilaksanakan apabila ada peran pemerintah daerah yang mendorong suatu kebijakan melalui sebuah kebijakan yang selaras pada program dan kegiatan pembangunan daerah ditiap sektor organisasi perangkat daerah yang ada. Hal ini akan dimungkinkan apabila pemerintah daerah membuatnya dalam sebuah bentuk produk hukum daerah yakni Peraturan Daerah (Perda) yang di dalamnya terdapat pengakuan, perlindungan, penghormatan dan pemberdayaan masyarakat hukum adat itu sendiri. Peraturan Perundang-Undangan diharapkan dapat menjadi salah satu instrumen untuk mewujudkan sistem Hukum Nasional yang dicita-citakan. Peraturan Perundang-Undangan dapat dikatakan baik (good legislation), jika sah menurut hukum (legal validity) dan berlaku efektif karena dapat diterima masyarakat secara wajar dan berlaku untuk waktu yang panjang.

Berdasarkan uraian diatas maka penulis tertarik untuk melakukan penelitian ilmiah dengan judul Kebijakan Pemerintah Daerah Dalam Melindungi Identitas Budaya Dan Hak Tradisional Masyarakat Hukum Adat Kabupaten Batang Hari. METODE PENELITIAN

Tipe penelitian yang digunakan adalah penelitian kualitatif dengan teknik purposive sampling yakni dengan mewawancarai orang yang mengetahui permasalahan yang diteliti serta studi terhadap data-data sekunder yang berasal dari berbagai referensi serta penelusuran situs-situs yang memuat hasil riset yang menjadi objek kajian.

\section{PEMBAHASAN}

\section{a. Kebijakan Pemerintah Daerah Dalam Melindungi Identitas Budaya Dan Hak Tradisional}

Undang-Undang Dasar Negara Republik Indonesia Tahun 1945 menempatkan negara pada posisi untuk mengakui dan menghormati setiap hak tradisional masyarakat adat dan suku yang masih hidup dan dilestarikan hingga hari ini. Dengan dimasukkannya pengakuan dan penghormatan terhadap hak tradisional, adat yang merupakan bagian dari hak tradisional adalah hak konstitusional yang juga merupakan hak asasi manusia. Dalam konstitusi hak-hak tradisional masyarakat hukum adat diatur dalam Pasal 18 B ayat (2) Undang-Undang Dasar Negara Republik Indonesia Tahun 1945 yang menyatakan bahwa, "Negara mengakui dan menghormati satuan-satuan komunitas hukum adat beserta adatnya. hak-hak selama mereka masih hidup dan sesuai dengan perkembangan masyarakat dan prinsip-prinsip Negara Kesatuan Republik Indonesia, diatur dalam hukum". Berdasarkan rumusan pasal, dapat dijelaskan bahwa:

1. bahwa negara mengakui keberadaan kesatuan adat masyarakat adat memang ada sebelum Negara Kesatuan Republik Indonesia didirikan dan UUD 1945 diratifikasi;

2. unit komunitas hukum adat yang diakui harus terbukti hidup;

3. bahwa pengakuan dapat berubah secara dinamis mengikuti perkembangan masyarakat dalam arti perkembangan zaman di mana perasaan kemanusiaan dan tingkat peradaban tumbuh dan berkembang sehingga pengakuan terhadap keberadaan masyarakat adat dan hak tradisional mereka juga harus disesuaikan. untuk kebutuhan sesuai dengan ruang dan waktu yang dinamis;

4. bahwa pengakuan juga tidak dapat bertentangan dengan prinsip dan kepentingan Negara Kesatuan Republik Indonesia, misalnya, di daerah perbatasan pengakuan ini tidak boleh berdampak negatif pada semangat persatuan nasional dan integritas teritorial Republik Kesatuan Republik Indonesia. karena wilayah hukum adat yang relevan melebihi batas wilayah Negara Kesatuan Republik Indonesia; dan 
5. bahwa persyaratan dan prosedur untuk mengakui masyarakat adat dan hakhak tradisional mereka harus diatur oleh hukum atau dalam hukum lain yang relevan.

\section{b. Bentuk Identitas Budaya dan Hak Tradisional hukum adat Kabupaten Batang Hari}

Kabupaten Batanghari memiliki delapan kabupaten. Pemerintah sedang berusaha mengembalikan budaya dan tradisi seni yang ada dengan cara mengidentifikasi dan meneliti serta mengeksplorasi potensi budaya yang ada di setiap kabupaten. Dalam hal ini untuk menghargai budaya yang telah disajikan kembali dalam pemerintahan masyarakat terutama departemen budaya dan pendidikan Batang Hari melakukan seni festival yang diadakan secara rutin setahun sekali. Tidak hanya menggelar festival tetapi juga menggelar kompetisi yang nantinya perlombaan ini tidak dimaksudkan untuk menemukan menang atau kalah tetapi hanya untuk menghargai seni dan memperkenalkannya ke masyarakat luas.

Dukungan yang diberikan oleh pemerintah dalam kegiatan ini dalam konteks pengembangan budaya, dengan memberikan dana untuk langsung ke masyarakat. Banyak budaya di masyarakat, salah satu daerah yang masih mempertahankan budayanya adalah di Kecamatan Rambutan Masam dimana kebudayaannya sangat dijaga. Kecamatan Muara bulian dan kecamatan Muara Tembesi memiliki studio paling banyak. Respon masyarakat dalam menanggapi upaya pelestarian budaya ini cukup positif karena banyak orang yang melaporkan bahwa budayanya harus dikembangkan karena hampir hilang dari zaman ke zaman.

\section{c. Kebijakan Pemerintah Daerah Dalam Melindungi Hukum Budaya Masyarakat Identitas Tradisional Dan hukum adat Kabupaten Batang Hari}

Budaya adalah kekayaan budaya bangsa sebagai wujud pemikiran dan perilaku hidup manusia yang penting bagi pemahaman dan pengembangan sejarah, sains, dan budaya dalam kehidupan bermasyarakat, berbangsa dan bernegara sehingga perlu dilestarikan dan dikelola dengan tepat. melalui upaya untuk melindungi, mengembangkan dan memanfaatkan untuk memajukan budaya nasional untuk kesejahteraan masyarakat secara maksimal.

Untuk melestarikan adat dan budaya, Negara bertanggung jawab atas pengaturan perlindungan, pengembangan dan pemanfaatan yang perlu dikelola oleh pemerintah dan pemerintah daerah dengan meningkatkan partisipasi masyarakat untuk melindungi, mengembangkan dan memanfaatkan pelestarian budaya dengan mengubah paradigma pelestarian Adat istiadat dan budaya, keseimbangan aspek ideologis, akademik, ekologis dan ekonomi diperlukan untuk meningkatkan kesejahteraan masyarakat.

Karakteristik adat dan tradisi antar kabupaten / kota di Provinsi Jambi, pada dasarnya memiliki kesamaan, tetapi dalam penerapannya di masing-masing daerah agak berbeda, sehingga kebiasaan dan budaya cenderung dibedakan sesuai dengan karakteristik masing-masing daerah.

Saat ini Pemerintah Kabupaten Batang Hari telah memiliki Peraturan Daerah No. 12 tahun 2018 tentang Identitas Daerah Batang Hari. Masalah perumusan kebijakan yang ada tidak disambut dengan kurangnya peraturan pelaksanaan untuk Peraturan Daerah.

Dalam pelestarian dan pengembangan nilai-nilai adat dan sosial dan budaya di Bumi secara simultan Regam dimaksudkan untuk memperkuat identitas individu dan masyarakat dalam bentuk pelestarian Identitas Regional. Dalam hal ini, kebijakan tersebut belum disosialisasikan dengan baik kepada semua pemangku kepentingan mengenai identitas budaya dan hak-hak tradisional masyarakat hukum adat di Kabupaten Batang Hari.

\section{KESIMPULAN}

Pelestarian adat dan budaya sebagai identitas daerah dalam kebijakan ini dimaksudkan agar: warisan budaya yang terkandung di Kabupaten Batang Hari dapat dilestarikan, meningkatkan martabat dan martabat budaya daerah melalui pelestarian adat dan budaya, memperkuat kepribadian 
masyarakat. bangsa; dan meningkatkan kesejahteraan masyarakat.

Seiring dengan implementasi kebijakan otonomi daerah, peran aktif daerah menjadi strategis untuk melakukan upaya-upaya untuk meningkatkan kesejahteraan masyarakat yang pada dasarnya adalah tujuan negara yang telah diamanatkan oleh konstitusi. Salah satunya adalah dengan melakukan upaya untuk melindungi, menghormati dan memberdayakan masyarakat adat dan lembaga adat di daerah. Pelaksanaan pemerintah daerah sesuai dengan prinsip otonomi berarti bahwa pemerintah daerah memiliki hak, wewenang dan kewajiban daerah otonom untuk mengatur dan mengelola Urusan Pemerintahan mereka sendiri dan kepentingan masyarakat setempat dalam sistem Negara Kesatuan Republik. Indonesia.

Berdasarkan uraian di atas, hasil tulisan ini dapat dikemukakan saran sebagai berikut:

Perlindungan dan penghormatan terhadap identitas budaya dan hak-hak tradisional masyarakat adat dan suku hanya akan dilakukan jika ada peran pemerintah daerah untuk mendorong kebijakan melalui kebijakan yang selaras dengan program dan kegiatan pembangunan daerah di setiap sektor. organisasi perangkat daerah yang ada. Ini akan dimungkinkan jika pemerintah daerah membuatnya dalam bentuk produk hukum daerah yaitu Peraturan Daerah di mana ada pengakuan, perlindungan, penghormatan dan pemberdayaan masyarakat hukum adat itu sendiri.

\section{DAFTAR PUSTAKA}

Bungin, Burhan, 2013, Metodologi Penelitian

Sosial Dan Ekonomi, Kencana Prenada

Media Group: Jakarta

Duwi, Priyanto. 2008. Mandiri Belajar SPSS,

MediaKom: Yogyakarta.

I Gde Pantja Astawa dan Suprin Na'a. 2008.

Dinamika Hukum dan Ilmu Perundang-Undangan di Indonesia, Alumni: Bandung.

Jimly Asshiddiqie. 2015. Konstitusi Masyarakat Desa (Piagam Tanggungjawab dan Hak Asasi
Manusia Warga Desa), Fakultas Hukum Universitas Indonesia.

Maria. S. W. Sumard jono. 1996. Kebijakan Pertanahan Antara Regulasi dan Implementasi, Penerbit Buku Kompas: Jakarta.

Mr. B. Ter Haar Bzn dan K. Ng. Soebakti Poesponoto. 1987. Asas-Asas dan Susunan Hukum Adat (Beginselen en Stelsel van Hat Adat Recht), PT.Pradnya Paramita: Jakarta.

Muhammad Tahir Azhary. 1992. Negara Hukum: Suatu Studi tentang PrinsipPrinsipnya. Dilihat dari Segi Hukum Islam, Implementasinya pada Periode Negara Madinah dan Masa Kini, Disertasi, Bulan Bintang: Jakarta.

Ni'matul Huda. 2006. Hukum Tata Negara, Rajagrafindo: Jakarta.

Nurcholis. 2005. Teori dan Praktik Pemerintahan dan Otonomi Daerah, Grasindo: Jakarta.

Sugiyono, 2014, Memahami Penelitian Kualitatif, Alfabeta: Bandung.

Tolib Setiady. 2009. Intisari Hukum Adat Indonesia, Alfabeta: Bandung. 